\title{
INDUSTRIE EN INDUSTRIALISATIE IN SURINAME
}

\author{
DOOR
}

W. R. Menkman

Dit is de titel van een rapport, voor de Caribbean Commission samengesteld door Ir J. E. Heesterman.

Het gedeelte dat den bestaanden toestand behandelt bevat, uit den aard der zaak, alleen in zover iets nieuws, dat de gegevens iets verder gaan dan die welke uit de tot dusver in druk verschenen Surinaamse Verslagen bekend waren.

Zo zien wij b.v. uit het rapport, dat in de periode 1937-1946 het totaal der belastbare inkomens van de in de inkomstenbelasting aangeslagenen in de laatste vijf jaren aanmerkelijk hoger was dan in de eerste, het aantal aanslagen eveneens. Het zou verlijdelijk zijn, de cijfers te vergelijken met de Nederlandse, bekend tot en met het jaar 1941, doch de fiscale regelingen zijn te verschillend.

Misschien geeft het door den Heer Heesterman gegeven cijfer van het Surinaamse nationale inkomen, door het Departement van Financiën zeer globaal geschat op 40 millioen per jaar, d.i. dus circa $f$ 200.- per hoofd der bevolking, iets meer houvast, met betrekking tot den welvaartstoestand. Voor Puerto Rico werd het nationale inkomen voor 1943 en 1944 geschat op ruim 200.- dollar per hoofd der bevolking, volgens een rapport van de U.S. Section of the Caribbean Commission. Ook deze vergelijking echter lijkt maar een zeer betrekkelijke waarde te hebben.

Min of meer tekenend voor den toestand is, dat volgens het rapport-Heesterman, het Surinaamse gouvernement in 1947 $f$ 9.300.000.- aan salarissen, lonen en pensioenen betaalde, de twee bauxiet-ondernemingen, de belangrijkste bedrijven van het land, aan salarissen en lonen iets meer dan $31 / 2$ millioen.

In het rapport wordt geconstateerd, dat er voor de industrie, zoals die thans aan het opkomen is, voldoende arbeidskrachten

$$
-166-
$$


aanwezig geacht kunnen worden, doch dat men, bij verdergaande uitbreiding, op immigratie aangewezen zou zijn.

Een staatje der vrachtprijzen voor het vervoer van Suriname naar Noordamerikaanse havens geeft voor koffie, om maar één artikel te noemen, een tarief dat hoog lijkt - en ook hoog is -, in vergelijking met hetgeen betaald moet worden op hetzelfde artikel, afkomstig uit andere Westindische productielanden, even ver van de marktplaatsen gelegen, maar niet hoog, vergeleken met de vracht berekend van soms dichter bij New York gelegen afscheephavens, welke in dezelfde minder gunstige omstandigheden verkeren als Paramaribo. Ons Suriname ligt niet op een met grote schepen veel bevaren route en heeft, althans wat landbouwproducten betreft, geen werkelijk belangrijke hoeveelheden te exporteren.

Hetgeen er, met betrekking tot het bedrijfswezen, over den landbouw gezegd wordt, beperkt zich tot enige gegevens aangaande rijst, waarvan de export nog steeds in handen van het gouvernement is en de cultuur gaandeweg gemechaniseerd wordt, suiker, waarvan de productie reeds in de laatste oorlogsjaren niet meer voldoende was om in de locale behoefte te voorzien, citrus- en andere vruchten, welke ter plaatse op bescheiden schaal ook tot sappen en conserven verwerkt worden, terwijl de uitvoer van sinaasappelen van 1946 weder belangrijk toegenomen is; en ten slotte cocos, welke niet voldoende olie opbrengt voor binnenlands gebruik, hoewel het gouvernement de productie tracht te stimuleren door opkoop tegen een redelijken prijs.

Van de bauxietnijverheid zegt het rapport, dat het aantal arbeiders - geschoolde en ongeschoolde-die er in 1946 een bestaan in vonden, 1647 bedroeg en de export in dat jaar al weder tot ruim een millioen ton gestegen was; volgens de intussen verschenen uitvoerstatistiek was 1947, een recordjaar, tot bijna 1.8 millioen ton. In 1948, zegt Ir Heesterman, zou het mogelijk worden ook het product uit te voeren der installatie tot het calcineren van bauxiet.

$\mathrm{Al}$ het in Suriname gewonnen goud, zo lezen wij verder, moet aan het deviezenfonds afgeleverd worden; er wordt van $f 1.80$ tot $f 2.11$ per gram voor betaald. De productie liep, van $495 \mathrm{~kg}$ in 1940, terug tot nog geen $145 \mathrm{~kg}$ in 1946.

Het grootbedrijf voor de bewerking van hout in Suriname (gezaagd hout en triplex) was bij het samenstellen van het rapport nog niet in actie; de opgenomen waarde van den uitvoer van hout, van alle soorten en in alle vormen, voor 1946 ongeveer 
832.000 gulden, beliep in 1947 reeds ruim 2.128.000 gulden.

Melding wordt gemaakt van de gunstige prijzen in het buitenland betaald voor de Surinaamse balata; inderdaad treedt een aanzienlijke stijging aan het licht, door een vergelijking der uitvoercijfers van de laatste jaren, $1945121.306 \mathrm{~kg}$ waarde $f 262.186$, $1946249.299 \mathrm{~kg}$ waarde $f 703.365,1947282.306 \mathrm{~kg}$ waarde $f$ 1.173.861. In drie jaar tijds nam de uitvoer dus kwantitatief toe met bijna $133 \%$, naar de waarde met bijna $348 \%$. Het zo sterk fluctueren der prijzen moet de balata-industrie tot een nogal onstabiel bedrijf maken.

Wat nu de fabrieksnijverheid betreft, somt het rapport een aantal kleine bedrijven op, welke uitsluitend op binnenlandsen afzet der producten aangewezen zijn. Er wordt thans iets meer voor eigen gebruik gefabriceerd dan zeg dertig jaar geleden, toen de bevolking iets meer dan half zo sterk was als tegenwoordig, maar indrukwekkend is de vooruitgang niet. Toch wordt in het rapport de mening uitgesproken, dat de binnenlandse markt nog vele mogelijkheden biedt voor nieuwe industrieën, hetzij dat gebruik gemaakt wordt van de grondstoffen welke het land zelf oplevert, of opleveren kan, hetzij dat ingevoerde grondstoffen verwerkt worden, waar dit met voordeel kan geschieden.

Het een en ander wordt overgenomen uit een ouder rapport, dat der Commissie voor de Naoorlogse Problemen. Overigens zij hier opgemerkt, dat het thans behandelde vraagstuk ook vroeger onder het oog gezien is, lang vóór den laatsten wereldoorlog en de stichting der Caribbean Commission. Wat verkregen zou moeten worden, is meer werkgelegenheid voor de bevolkingsgroep der Creolen, die thans ò een armelijk bestaan leiden, dan wel, daartoe in staat gesteld door de in eigen land genoten opleiding, elders een goed heenkomen zoeken - en dan ten tweede, wat niet minder belangrijk is, verbetering der handelsbalans.

Dat er aan verdere industrialisatie, al ware het alleen maar met het doel de binnenlandse markt te voorzien van goederen welke tot dusver geïmporteerd werden, grote moeilijkheden verbonden zullen zijn, ligt wel zeer voor de hand, om van een exportindustrie niet eens te spreken. Dat de overheid de industriële ontwikkeling kan stimuleren, door financiële hulp en door voorlichting, moge juist zijn, maar daarmede is niet alles gezegd. En, steun in den vorm van beschermende invoerrechten maakt voor den binnenlandsen consument de goederen duur, houdt bovendien het aanbrengen van verbeteringen in het productieproces tegen, terwijl de exportmogelijkheid verdwijnt. Alles oude argu- 
menten, welke voor Suriname evenzeer gelden als voor andere landen.

Ook is er, om de industrialisatie te doen slagen, nog iets meer nodig dan de beschikking over kapitaal en de aanwezigheid van arbeidskrachten, geschoolde of voor opleiding vatbare. Er moet ook een leiding zijn, met technische en commerciele kwaliteiten. Zal er aan al deze eisen voldaan kunnen worden, terwijl er voorlopig slechts sprake zal kunnen zijn van de voorziening in de behoeften ener weinig talrijke en weinig koopkrachtige bevolking?

Er valt inderdaad, het is reeds gezegd, enige vooruitgang op industrieel gebied te constateren in Suriname; men vergelijke slechts het overzicht dat Ir Heesterman geeft, grotendeels betrekking hebbend op het jaar 1946, met dat hetwelk te vinden is in het Surinaams Verslag over 1939. Maar, er is intussen vijf jaar oorlog geweest, met alle daaraan verbonden belemmeringen op het gebied van handel en verkeer. In hoever is de opleving aan deze omstandigheid te danken geweest en welke kansen zal de Surinaamse nijverheid blijken te hebben, wanneer aan den drang tot export in de grote industrielanden geen belemmeringen meer in den weg zullen staan?

Belangrijke beschouwingen vinden wij in hoofdstuk VI van het rapport-Heesterman, handelende over Coördinatie en Rationalisatie en tevens betrekking hebbend op de Nederlandse Antillen.

In de overeenkomst tussen Nederland, Frankrijk, GrootBrittannië (met Noord Ierland) en de Verenigde Staten van Amerika (S. 1948 No I 447) wordt gesproken van coördinatie en onderlinge samenwerking; Ir Heesterman interpreteert het gegeven principe zó, dat de economische eenheid van het Caraibische gebied in zijn geheel als einddoel gezien moet worden. Terecht, zou men zeggen.

Hij wijst er op, dat thans drie van de vier leden der Caraibische Commissie een nijpend gebrek hebben aan buitenlandse betaalmiddelen en dat er daarom eerder een neiging bij hen bestaat om de economische betrekkingen tot de respectieve overzeese gebiedsdelen te versterken, dan om de samenwerking te bevorderen van die gebiedsdelen onderling, waardoor deze laatste voor de voorziening in hun materiële behoeften minder van de moederlanden afhankelijk zouden worden. 
Wat wij tegenwoordig noemen het Caraibische gebied, dus met inbegrip van de drie Guyanas onder Europese souvereiniteit en Brits Honduras, als één geheel gezien, beschikt over grondstoffen, of kan den bodem grondstoffen doen voortbrengen, welke zouden kunnen dienen voor de productie van tal van goederen welke dat gebied, wederom als één geheel gezien, verbruikt en tot dusver grotendeels, of in totaal, uit Europa en Noord Amerika betrekt.

Waarin de coördinatie en de rationalisatie zouden moeten bestaan, is duidelijk genoeg. Iedere afzonderlijke industrie zou gevestigd moeten worden dáár waar dit het doelmatigst zou blijken (in verband met arbeids-, grondstoffen- en verkeerspositie) en het verkregen product zou moeten voorzien in de daaraan bestaande behoefte, in het eigen en in het gehele overige Caraibische gebied. Een onderlinge uitwisseling derhalve van grondstoffen en afgewerkte producten, wat ook gepaard zou gaan met een geheel nieuwe ontwikkeling in het onderlinge verkeer ter zee.

Deze uiterste consequentie, een zoveel mogelijk ,,self supporting" Caraibisch gebied, lijkt wel volkomen theoretisch; men zou maatregelen moeten nemen om alle belemmeringen van het onderlinge verkeer weg te nemen (de fiscale niet in de laatste plaats), wellicht ook om de concurrentie van buitenaf te weren, grotere en kleinere plaatselijke belangen ter zijde moeten stellen enz. Het lijkt een beau idéal, in de practijk niet voor verwezenlijking vatbaar.

Ir Heesterman gaat dan ook in zijn rapport niet zó ver en bepaalt zich tot het aangeven van enige middelen om de economische eenheid van het Caraibische gebied althans iets naderbij te brengen. Als daar zijn: maatregelen om onbehoorlijke concurrentie van buitenaf te bestrijden, om den onderlingen handel te vergemakkelijken (deviezen-moeilijkheden), om de scheepvaart-verbindingen te verbeteren, om te voorkomen dat onnodig eenzelfde industrie op verschillende plaatsen gevestigd wordt en eindelijk om een inzicht te verkrijgen in de mogelijkheden welke misschien de waterkracht bieden kan in de drie Guyanas.

Natuurlijk zijn dit aanbevelingen en anders niet; de bevoegde organen der Caribbean Commission zullen een en ander in studie hebben te nemen, om dan op hun beurt te adviseren aangaande de mogelijke uitvoering.

Het geheel der tot dusver in druk verschenen publicaties van de Caribbean Commission getuigt van een enorme activiteit op 
het gebied van studie en onderzoek; dit alleen reeds mag als een belangrijk voordeel beschouwd worden voor de territoria in West Indië onder de souvereiniteit der vier verdragslanden. Men kan slechts wensen en hopen dat er ook voor Suriname iets goeds zal voortvloeien uit de moeite welke gedaan wordt om de gezamenlijke Westindische problemen althans te leren kennen, in alle onderdelen en schakeringen. 